\title{
THERMAL FATIGUE OF SINGLE-CRYSTAL SUPERALLOYS: EXPERIMENTS, CRACK-INITIATION AND CRACK-PROPAGATION CRITERIA
}

\author{
TOPLOTNO UTRUJANJE MONOKRISTALNIH SUPERZLITIN: \\ PREIZKUSI, MERILA ZA NASTANEK IN NAPREDOVANJE \\ RAZPOKE
}

\author{
Leonid Getsov¹, Artem Semenov², Sergey Semenov², Alexander Rybnikov', \\ Elena Tikhomirova ${ }^{3}$ \\ ${ }^{1}$ NPO CKTI, Saint-Petersburg, Russia \\ ${ }^{2}$ Saint-Petersburg State Polytechnical University, Russia \\ ${ }^{3}$ Klimov Company, Saint-Petersburg, Russia \\ guetsov@yahoo.com,semenov.artem@googlemail.com \\ Prejem rokopisa - received: 2014-10-03; sprejem za objavo - accepted for publication: 2014-11-06
}

doi:10.17222/mit.2014.251

Thermal-fatigue tests were performed on corset samples made from five single-crystal nickel-based superalloys with various crystallographic orientations $(\langle 001\rangle,\langle 011\rangle,\langle 111\rangle)$ at different temperatures and cycle durations. The proposed criteria for the thermal-fatigue crack initiation and crack propagation are discussed and compared with experimental results. The sensitivity of durability to the crystallographic orientation and to thermal-cycle parameters is analyzed experimentally and by means of the corresponding finite-element simulations.

Keywords: nickel-based superalloy, single crystal, thermal fatigue, crack initiation, crack propagation

Preizkusi toplotnega utrujanja so bili izvršeni na vzorcih korzetne oblike. Vzorci so bili izdelani iz petih monokristalnih nikljevih superzlitin z različno kristalografsko orientacijo $(\langle 001\rangle,\langle 011\rangle,\langle 111\rangle)$, preizkusi pa so bili narejeni pri različnih temperaturah trajanja ciklov. Predlagana merila za nastanek razpok in njihovo napredovanje pri toplotnem utrujanju so opisana in primerjana z eksperimentalnimi rezultati. Odvisnost zdržljivosti od kristalografske orientacije in parametrov toplotnih ciklov je eksperimentalno analizirana in ugotovljena z ustrezno simulacijo s končnimi elementi.

Ključne besede: superzlitina na osnovi niklja, monokristal, toplotno utrujanje, nastanek razpok, napredovanje razpoke

\section{EXPERIMENTAL DATA}

The durability of the single-crystal blades of modern gas turbines is mainly determined by their ability to resist the thermal-cycling stress. In Russia, the testing of the thermal fatigue of corset samples (Figure 1) in vacuum conditions, with and without lateral thermal-bar-

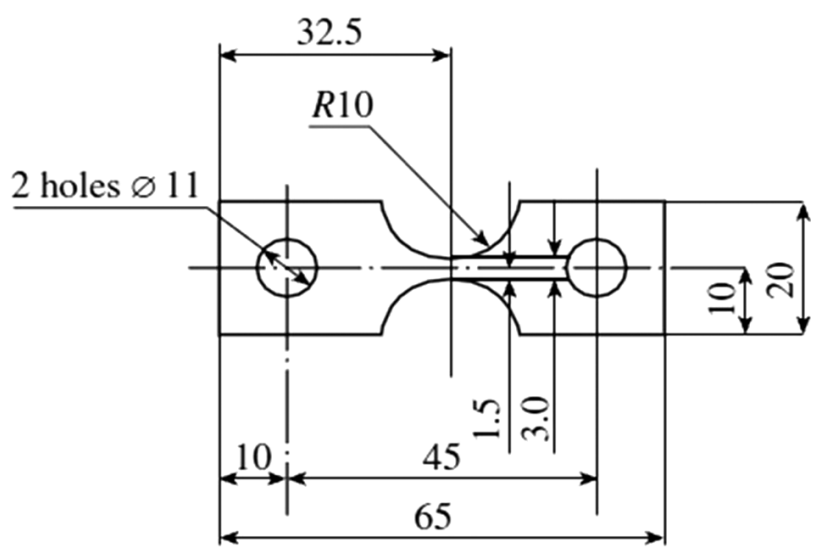

Figure 1: Specimen for thermal-fatigue tests

Slika 1: Vzorec za preizkus toplotnega utrujanja rier coatings is widespread. During the test, the shearband formation, the conditions of crack nucleation and the rate of crack propagation are investigated.

Experimental studies were performed on five singlecrystal alloys (ZhS32, ZhS36 and others) developed by the VIAM research centre, with different alloying and, most importantly, different carbon contents. The chemical compositions of the alloys are given in Table $\mathbf{1}$.

The tests of the thermal-fatigue resistance were carried out for different crystallographic orientations (CGOs) of the specimens, various minimum $\left(T_{\min }\right)$ and maximum temperatures $\left(T_{\max }\right)$ of the cycle, with and without a dwell time at $T_{\max }{ }^{1,2}$ The test results were characterized with the number of cycles to the macrocrack initiation and to the failure of the samples and the in-plane and out-of-plane residual strains $\left(\varepsilon_{\text {in }}, \varepsilon_{\text {out }}\right)$ in the central parts of the specimens. The changing of $T_{\max }$ and CGO has a significant influence on the thermal-cycling durability (Table 2).

The results of a comparative analysis of the thermalfatigue durabilities of the five considered alloys are given in Figure 2, for a thermal cycle of $150 \leftrightarrow 900{ }^{\circ} \mathrm{C}$ (Figures 2a and 2c) and for a cycle of $500 \leftrightarrow 1050{ }^{\circ} \mathrm{C}$ (Figures 2b and 2d). 
L. GETSOV et al.: THERMAL FATIGUE OF SINGLE-CRYSTAL SUPERALLOYS: EXPERIMENTS, ...

Table 1: Chemical compositions of Ni-based single-crystal alloys ( $w / \%)$

Tabela 1: Kemijska sestava monokristalnih zlitin na osnovi Ni (w/\%)

\begin{tabular}{|c|c|c|c|c|c|c|c|c|c|c|c|c|c|c|c|}
\hline & $\mathrm{C}$ & $\mathrm{Cr}$ & $\mathrm{Co}$ & Mo & $\mathrm{W}$ & $\mathrm{Ta}$ & $\mathrm{Re}$ & $\mathrm{Al}$ & $\mathrm{Ti}$ & $\mathrm{Nb}$ & $\mathrm{Re}$ & $\mathrm{La}$ & $\mathrm{Ru}$ & $\mathrm{Ze}$ & $\mathrm{Si}$ \\
\hline Alloy 1 & $\begin{array}{c}0.12- \\
0.18\end{array}$ & $4.3-5.6$ & $\begin{array}{l}8.0- \\
10.0\end{array}$ & $0.8-1.4$ & $7.7-9.5$ & $3.54-5$ & $3.5-4.5$ & $5.6-6.3$ & - & $1.4-1.8$ & - & - & - & - & - \\
\hline Alloy 2 & 0.05 & 4.5 & 9.0 & 1.5 & 12.0 & & 2.0 & 5.9 & 1.0 & 1.0 & 2.0 & - & - & - & - \\
\hline Alloy 3 & $<0.02$ & 2.85 & 6.20 & 4.0 & 3.8 & 4.5 & 6.2 & 6.0 & - & - & - & - & 3.9 & & $<0.2$ \\
\hline Alloy 4 & $<0.02$ & 4.2 & 8.3 & 1.8 & 5.1 & 6.1 & 4.05 & 6.0 & 0.8 & - & - & - & - & - & $<0.2$ \\
\hline Alloy 5 & $<0.02$ & $3.2-3.8$ & $4.6-5.4$ & $4.2-4.8$ & $2.2-2.8$ & $5.7-6.3$ & $\begin{array}{c}0.25- \\
0.55\end{array}$ & $8.1-8.6$ & - & - & - & $0.01-0.2$ & - & $<0.02$ & $<0.2$ \\
\hline
\end{tabular}

a)

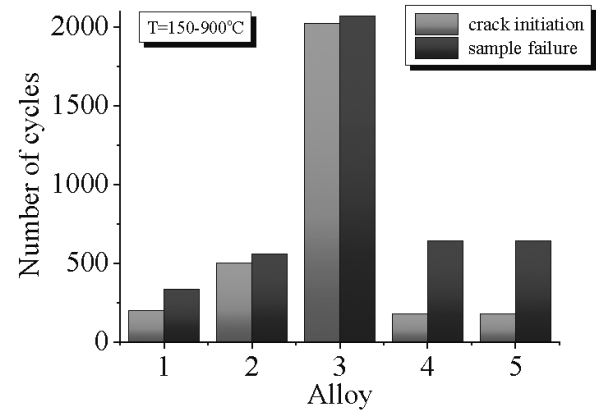

b)

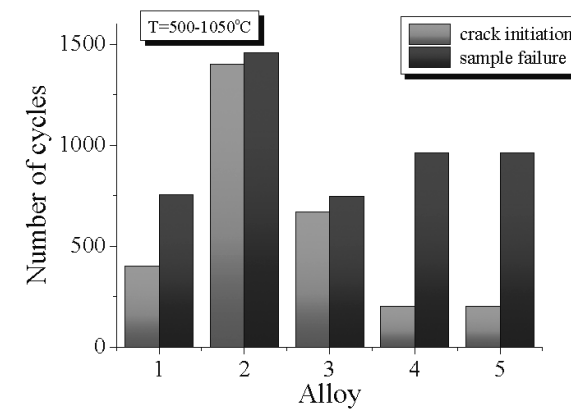

c)

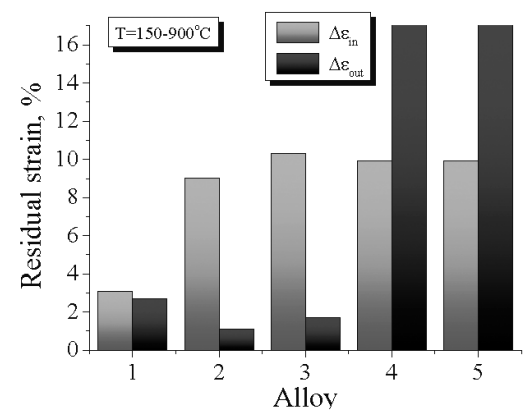

d)

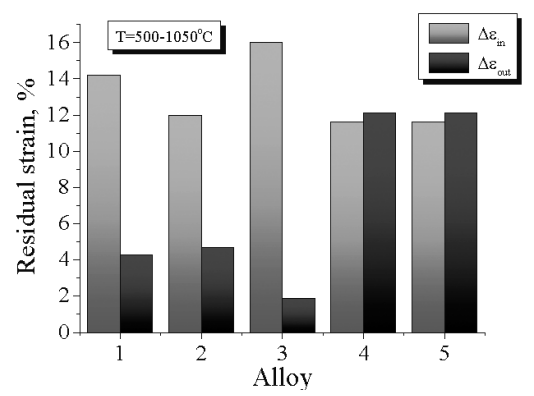

Figure 2: Comparison of thermal-fatigue resistance values for alloys 1-5 (number of cycles $(\mathrm{a}, \mathrm{b})$ and transversal residual strains at failure (c, d) for cycles of $150 \leftrightarrow 900{ }^{\circ} \mathrm{C}(\mathrm{a}, \mathrm{c})$ and $500 \leftrightarrow 1050{ }^{\circ} \mathrm{C}(\mathrm{b}, \mathrm{d})$ ).

Slika 2: Primerjava odpornosti proti toplotnemu utrujanju zlitin 1-5 (število ciklov $(\mathrm{a}, \mathrm{b})$ in prečne preostale napetosti pri porušitvi (c, d) pri ciklih od $150 \leftrightarrow 900{ }^{\circ} \mathrm{C}(\mathrm{a}, \mathrm{c})$ in $\left.500 \leftrightarrow 1050{ }^{\circ} \mathrm{C}(\mathrm{b}, \mathrm{d})\right)$
Table 2: Effects of cycle temperature and CGO (alloy 2)

Tabela 2: Vpliv temperature cikliranja in CGO (zlitina 2)

\begin{tabular}{|c|c|c|c|c|}
\hline \multirow{3}{*}{ Orientation } & $\Delta T /{ }^{\circ} \mathrm{C}$ & $T_{\min } /{ }^{\circ} \mathrm{C}$ & $T_{\max } /{ }^{\circ} \mathrm{C}$ & $\begin{array}{c}\text { Number of } \\
\text { cycles to } \\
\text { failure }\end{array}$ \\
\hline \multirow{3}{*}[001]{} & \multirow{3}{*}{750} & 150 & 900 & 951 \\
\cline { 3 - 5 } & \multirow{3}{*}{500} & 200 & 950 & 450 \\
\cline { 3 - 5 } & & 250 & 1000 & 63 \\
\cline { 3 - 5 } & \multirow{2}{*}{750} & 550 & 950 & 2635 \\
\cline { 3 - 5 } & & 500 & 1000 & 1220 \\
\hline \multirow{2}{*}[011]{} & & 250 & 1050 & 356 \\
\hline
\end{tabular}

Table 3: Effects of dwell time at $T_{\max }$ and of aging on the thermalfatigue resistance for alloy 3 at thermal cycle of $500 \leftrightarrow 1050{ }^{\circ} \mathrm{C}$

Tabela 3: Vpliv zdržljivosti pri $T_{\max }$ in staranja na odpornost proti toplotnemu utrujanju zlitine 3 pri toplotnem cikliranju $500 \leftrightarrow 1050{ }^{\circ} \mathrm{C}$

\begin{tabular}{|c|c|c|c|c|}
\hline $\begin{array}{c}\text { Condition and test } \\
\text { mode }\end{array}$ & $\begin{array}{c}\text { Number of } \\
\text { cycles to } \\
\text { macrocrack }\end{array}$ & $\begin{array}{c}\text { Number of } \\
\text { cycles to } \\
\text { failure }\end{array}$ & $\varepsilon_{\text {in }} / \%$ & $\varepsilon_{\text {out }} / \%$ \\
\hline $\begin{array}{c}\text { Without a dwell time } \\
\text { at } T_{\max }\end{array}$ & 670 & 746 & 16 & -1 \\
\hline $\begin{array}{c}\text { Dwell time of } 2 \mathrm{~min} \\
\text { at } T_{\max }\end{array}$ & 27 & 91 & 12 & 17 \\
\hline $\begin{array}{c}\text { Aging at } 850{ }^{\circ} \mathrm{C}, \\
500 \mathrm{~h}\end{array}$ & 85 & 242 & 13 & 4 \\
\hline
\end{tabular}

$\varepsilon_{\text {in }}, \varepsilon_{\text {out }}-$ residual strains in 2 directions transversal to the sample axis

The obtained results indicate a relatively weak influence of the chemical composition of the single-crystal alloys on the thermal-fatigue durability (the differences are less than 2-5 times). On the other hand, the longterm strengths and creep-resistance values of the singlecrystal alloys with different compositions differ quite significantly. ${ }^{3}$ None of the alloys among 1-5 demonstrates the maximum durability throughout the whole thermal-cycling-parameter range.

A significant decrease in the durability is observed after the dwell time at the maximum temperature of the cycle (Table 3). The preliminary aging at $850{ }^{\circ} \mathrm{C}$ also leads to a considerable decrease in the durability and residual strains.

\section{CRITERION FOR THE TMF-CRACK INITIATION}

The prediction of the thermo-mechanical-fatigue (TMF) failures of the single-crystal materials is per- 
formed on the basis of the deformation criterion. ${ }^{4-6}$ The macrocrack-initiation criterion is the condition for achieving the critical value of the total damage initiated by different mechanisms:

$$
D_{1}\left(\Delta \varepsilon_{\mathrm{eq}}^{\mathrm{p}}\right)+D_{2}\left(\Delta \varepsilon_{\mathrm{eq}}^{\mathrm{c}}\right)+D_{3}\left(\varepsilon_{\mathrm{eq}}^{\mathrm{p}}\right)+D_{4}\left(\varepsilon_{\mathrm{eq}}^{\mathrm{c}}\right)=1
$$

Criterion (1) is based on the linear damage summation of the cyclic plastic strain:

$$
D_{1}=\sum_{i=1}^{n} \frac{\left(\Delta \varepsilon_{\mathrm{eq}_{i}}^{\mathrm{p}}\right)^{\mathrm{k}}}{\mathrm{C}_{1}\left(T_{i}\right)}
$$

cyclic creep strain:

$$
D_{2}=\sum_{i=1}^{n} \frac{\left(\Delta \varepsilon_{\mathrm{eq}_{i}}^{\mathrm{c}}\right)^{\mathrm{m}}}{\mathrm{C}_{2}\left(T_{i}\right)}
$$

one-sided accumulated plastic strain:

$$
D_{3}=\max _{0 \leq t \leq t_{\max }} \frac{\varepsilon_{\mathrm{eq}}^{\mathrm{p}}}{\varepsilon_{\mathrm{r}}^{\mathrm{p}}(T)}
$$

and one-sided accumulated creep strain:

$$
D_{4}=\max _{0 \leq t \leq t_{\max }} \frac{\varepsilon_{\mathrm{eq}}^{\mathrm{c}}}{\varepsilon_{\mathrm{r}}^{\mathrm{c}}(T)}
$$

where $C_{1}, C_{2}, k, m, \varepsilon_{\mathrm{r}}^{\mathrm{p}}, \varepsilon_{\mathrm{r}}^{\mathrm{c}}$ are the material parameters, depending on the temperature and crystallographic orientation. Usually the material parameters $k=2, m=$ $5 / 4, C_{1}=\left(\varepsilon_{\mathrm{r}}\right)^{\mathrm{p}}, C_{2}=\left(3 / 4 \varepsilon_{\mathrm{r}}^{\mathrm{c}}\right)^{\mathrm{m}}$ are used. ${ }^{4}$

Different norms of the strain tensor are considered as the equivalent strains for (1)-(5), including the maximum shear strain in the slip system with normal $\mathbf{n}_{\{111\}}$ to the slip plane and slip direction $\mathbf{l}_{\langle 011\rangle}$ :

$$
\varepsilon_{\text {eq }}=\mathbf{n}_{\{111\}} \cdot \boldsymbol{\varepsilon} \cdot \mathbf{l}_{\langle 011\rangle}
$$

the maximum principal strain (the maximum eigenvalue of the strain tensor):

$$
\varepsilon_{\text {eq }}=\varepsilon_{1}=\max \arg \{\operatorname{det}(\boldsymbol{\varepsilon}-\lambda \mathbf{l})=0\}
$$

the von Mises strain intensity:

$\varepsilon_{\mathrm{eq}}=\sqrt{\frac{2}{9}\left[\left(\varepsilon_{x}-\varepsilon_{y}\right)^{2}+\left(\varepsilon_{y}-\varepsilon_{z}\right)^{2}+\left(\varepsilon_{z}-\varepsilon_{x}\right)^{2}\right]+\frac{1}{3}\left(\gamma_{x y}^{2}+\gamma_{y z}^{2}+\gamma_{z x}^{2}\right)}$

the Hill strain intensity:

$\varepsilon_{\mathrm{eq}}=\sqrt{\frac{2}{9}\left[\left(\varepsilon_{x}-\varepsilon_{y}\right)^{2}+\left(\varepsilon_{y}-\varepsilon_{z}\right)^{2}+\left(\varepsilon_{z}-\varepsilon_{x}\right)^{2}\right]+\frac{1}{K^{*}}\left(\gamma_{x y}^{2}+\gamma_{y z}^{2}+\gamma_{z x}^{2}\right)}$

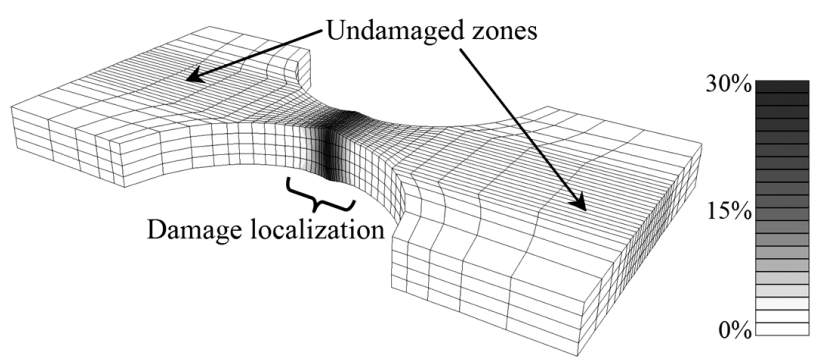

Figure 3: Damage-field distribution after the $10^{\text {th }}$ cycle for sample 43 from alloy 3 with near to $\langle 001\rangle$ orientation

Slika 3: Razporeditev polja poškodbe po 10 . ciklu za vzorec 43 iz zlitine $3 \mathrm{z}$ orientacijo blizu $\langle 001\rangle$ and the maximum shear strain:

$$
\varepsilon_{\mathrm{eq}}=\frac{1}{2}\left(\varepsilon_{1}-\varepsilon_{3}\right)
$$

Equivalent strains (6) and (9) correspond to the crystallographic failure mode, while equivalent strains (7), (8) and (10) correspond to the non-crystallographic failure mode. In (9):

$$
K^{*}=9\left[4\left(\frac{\varepsilon_{r\langle 001\rangle}}{\varepsilon_{r\langle 011\rangle}}\right)^{2}-1\right]^{-1}
$$

\section{RESULTS OF THE FINITE-ELEMENT SIMULATION}

In order to verify criterion (1) a stress-strain analysis of the single-crystal corset samples (Figure 1) was carried out using the finite-element (FE) program PANTOCRATOR $^{7}$ with an application of physical models of elastoplasticity. These material models take into account the fact that inelastic deformation occurs in accordance with the crystal slip system due to a slip mechanism and, therefore, the deformation is strongly sensitive to the crystallographic orientation. The elastoplastic and visco-elasto-plastic material models ${ }^{8,9}$ with nonlinear kinematic and isotropic hardening, also including the self-hardening of each system and the latent hardening ${ }^{10}$ between the slip systems, are used in the FE simulations. The application of the visco-elastic models leads to unrealistically overestimated levels of the stress.

The obtained results for the inhomogeneous stress, strain and damage fields allowed us to find the location of the crack initiation. The damage field is determined with criterion (1) on the basis of an analysis of the strain-field evolution using the experimental data on creep- and elastoplastic-deformation curves. The typical damage field distribution after the $10^{\text {th }}$ cycle $\left(20{ }^{\circ} \mathrm{C} \rightarrow T_{\max }=900{ }^{\circ} \mathrm{C} \leftrightarrow T_{\min }=150{ }^{\circ} \mathrm{C}\right)$ is presented in Figure 3 for the sample from alloy 3 with the orientation near to $\langle 001\rangle$. The best prediction (in comparison with

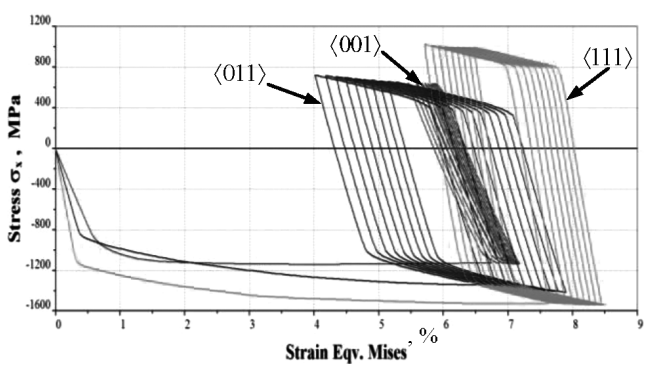

Figure 4: Influence of the crystal orientation on the cyclic stressstrain curve. Results of finite-element simulations of thermal cycles with $T_{\min }=150{ }^{\circ} \mathrm{C}$ and $T_{\max }=900{ }^{\circ} \mathrm{C}$ (the central point of a specimen).

Slika 4: Vpliv orientacije kristala na ciklično krivuljo napetost raztezek. Rezultati simulacije s končnimi elementi za toplotne cikle s $T_{\min }=150{ }^{\circ} \mathrm{C}$ in $T_{\max }=900{ }^{\circ} \mathrm{C}$ (sredina vzorca). 
$\langle 001\rangle$

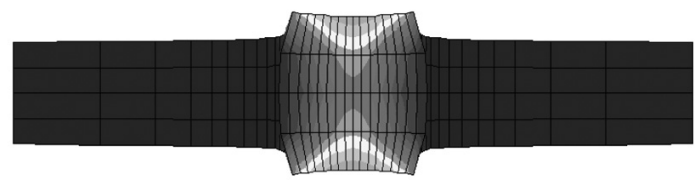

$\langle 011\rangle$

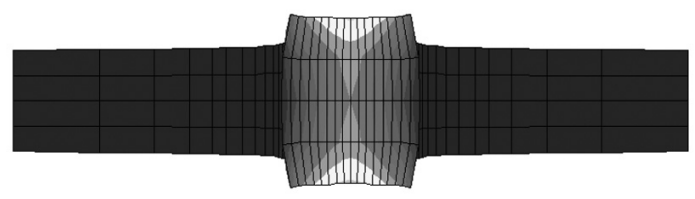

$\langle 111\rangle$

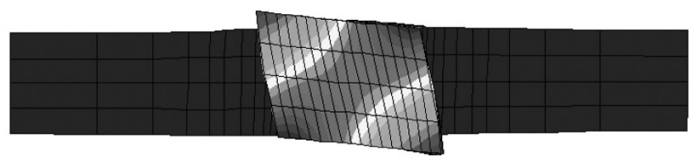

Figure 5: Comparison of deformed states (for clarity increased 10 times) of the central sections of the specimens with orientations $\langle 001\rangle$, $\langle 011\rangle$ and $\langle 111\rangle$ for the cooling phase $\left(T=150^{\circ} \mathrm{C}\right)$ after the $10^{\text {th }}$ cycle. Colors show the damage-field distribution.

Slika 5: Primerjava deformacijskih stanj (za boljšo prepoznavnost povečano 10-krat) v srednjem prerezu vzorcev $\mathrm{z}$ orientacijo $\langle 001\rangle$, $\langle 011\rangle$ in $\langle 111\rangle$ pri fazi ohlajanja $\left(T=150{ }^{\circ} \mathrm{C}\right)$ po 10 . ciklu. Barve prikazujejo področje razporeditve poškodbe.

the experiment) of the number of cycles for the crack initiation is given for strain measure (6) in this loading case.

The results of the FE simulations show that the crystallographic orientation has a significant influence on the stress-strain state of the samples (Figures $\mathbf{4}$ and 5) which was also confirmed with the experiments. ${ }^{10}$

The results of the verification of criterion (1) for alloys 2 and 3 are given in Figure 6. The computed number of the cycles to crack initiation demonstrates a satisfactory accuracy.

The thermal-fatigue failure process for the corset specimens shows the presence of two distinct modes (cry-

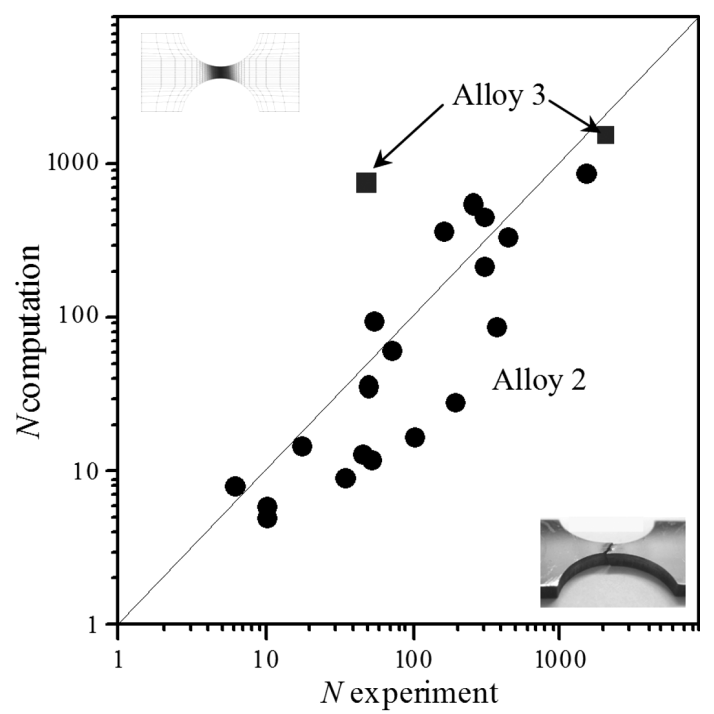

Figure 6: Comparison of experimental data with the results of computations of thermal-fatigue durability for alloys 2 and 3

Slika 6: Primerjava eksperimentalnih podatkov z rezultati izračunov odpornosti proti termičnemu utrujanju za zlitini 2 in 3

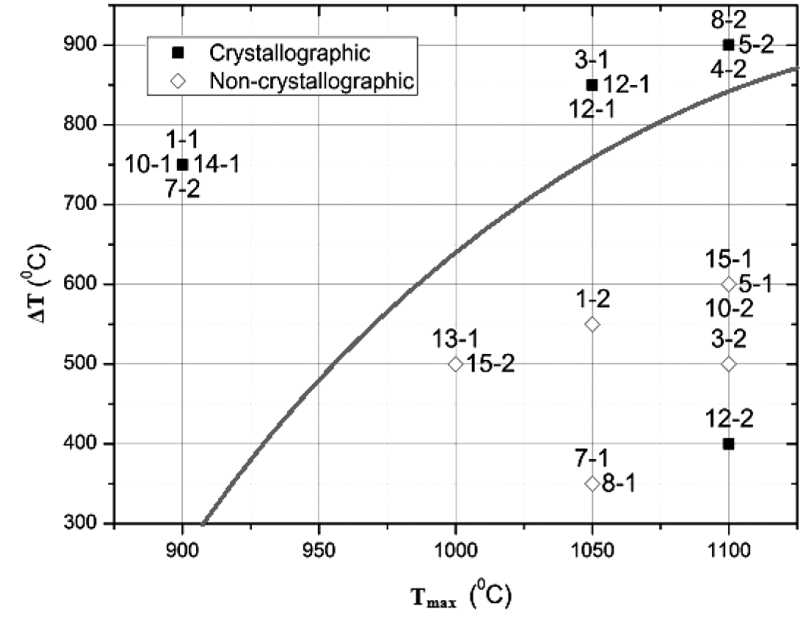

Figure 7: Diagram of thermal-fatigue failure modes (alloy 1)

Slika 7: Diagram vrste poškodb pri toplotnem utrujanju (zlitina 1)

stallographic and non-crystallographic) of the failure. Their occurrence depends on the CGO and on temperatures $T_{\min }$ and $T_{\max }$ of the cycle. The experimental results and the Arrhenius approximation of the boundary between the failure modes are given in Figure 7. The difference in the failure mode is taken into consideration for the damage computation based on equation (1) by choosing the equivalent strain measure (6)-(10) and analysing the crack propagation by choosing the direction of the crack growth.

The results of the experiments and computations showed that the dwell time has a significant effect on the thermal-fatigue durability. Figure $\mathbf{8}$ shows the computed effect of the influence of the dwell time at $T_{\max }$ on the thermal-fatigue durability for the specimen from alloy 3 and for the thermal cycle of $T_{\min }=500{ }^{\circ} \mathrm{C} \leftrightarrow T_{\max }=1050{ }^{\circ} \mathrm{C}$. A comparison of the numbers of the cycles to crack initiation computed with equation (1) and obtained with the experimental results is given in Table 4.

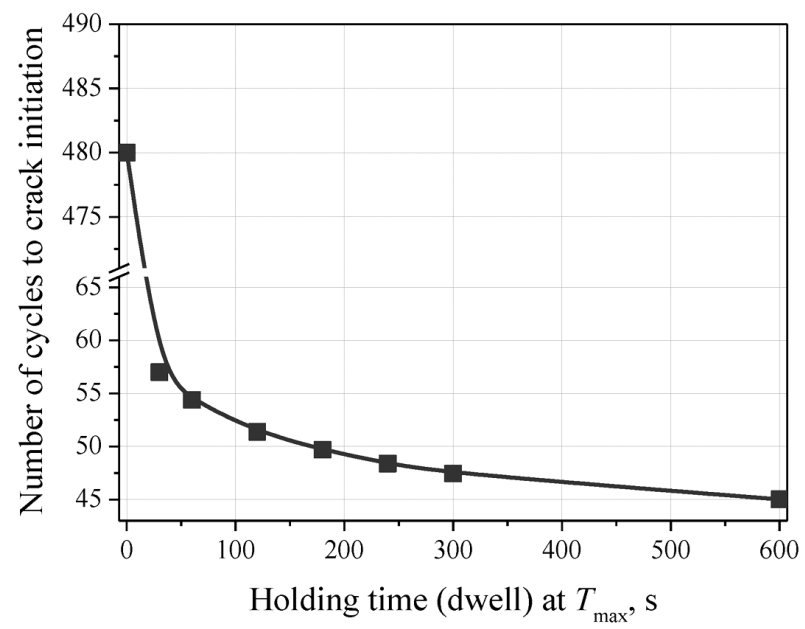

Figure 8: Influence of the dwell time at $T_{\max }$ on the thermal-fatigue durability (alloy 3)

Slika 8: Vpliv časa zadržanja pri $T_{\max }$ na zdržljivost pri toplotnem utrujanju (zlitina 3) 
Table 4: Comparison of the numbers of the cycles to crack initiation obtained with the computation and with the experiment for various dwell times at $T_{\max }$ (alloy 3)

Tabela 4: Primerjava izračunanega števila ciklov do nastanka razpoke in eksperimentalnih rezultatov pri različnih časih zadržanja na $T_{\max }$ (zlitina 3)

\begin{tabular}{|l|c|c|}
\hline \multirow{2}{*}{} & \multicolumn{2}{|c|}{ Dwell time } \\
\cline { 2 - 3 } & $0 \mathrm{~s}$ & $120 \mathrm{~s}$ \\
\hline Computation with (1) & 480 & 45 \\
\hline Experiment & 670 & 27 \\
\hline
\end{tabular}

Alloys 1-5 have significantly different creep characteristics and creep-rupture strengths, therefore it can be expected that the thermal-fatigue durability in the case of a dwell time at $T_{\max }$ varies significantly for different alloys, contrary to the cases of no dwell time at $T_{\max }$.

\section{CRITERION FOR THE TMF-CRACK PROPAGATION}

The direction of a crack propagation in a single crystal is defined by the crystallographic structure (typically it is plane $\langle 111\rangle$ for the considered alloys ${ }^{11,12}$ in the crystallographic mode of failure) and, correspondingly, it is defined by the stress state during the non-crystallographic failure mode (a high temperature).

The criterion for the thermal-fatigue-crack propagation, ${ }^{13}$ based on a linear sum of the contributions of the fatigue and creep, is used in order to determine the rate of crack propagation and the number of cycles to failure. The criterion is based on using stress-intensity factor $\Delta K_{\text {eff }}$ (for the description of the fatigue) and the $C^{*}$-integral (for the description of the creep during the dwell time at the maximum temperature of the cycle). The mathematical formulation of the criterion represents a generalization of the Paris power-type equation by taking into account two mechanisms of cracking: ${ }^{13}$

$$
\frac{\mathrm{d} a}{\mathrm{~d} N}=B\left(\Delta K_{\text {eff }}\right)^{\mathrm{m}}+\int_{0}^{t_{\mathrm{y}}} A(C *(\tau))^{\mathrm{q}} \mathrm{d} \tau
$$

where $A, B, m, q$ are the material constants, defined separately from the fatigue experiments as $\mathrm{d} a / \mathrm{d} N\left(\Delta K_{\text {eff }}\right)$ and creep experiments as $\mathrm{d} a / \mathrm{d} t\left(C^{*}\right)$ crack-growth data.

The crack-propagation process in the corset sample (Figure 1) from alloy 2 is simulated cycle by cycle using a)

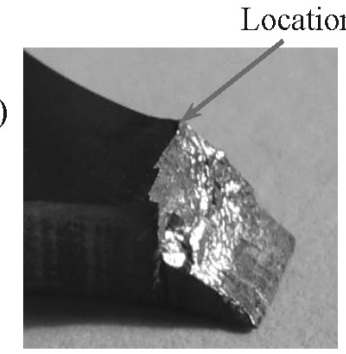

b)

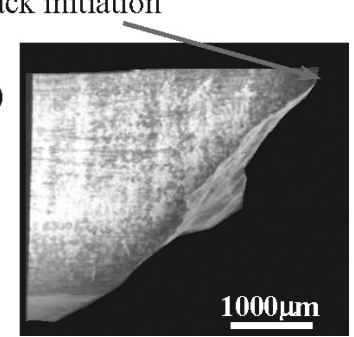

Figure 9: Views of the specimen from alloy 2 after the failure: a) left half, b) right half

Slika 9: Videz vzorca zlitine 2 po porušitvi: a) leva polovica, b) desna polovica

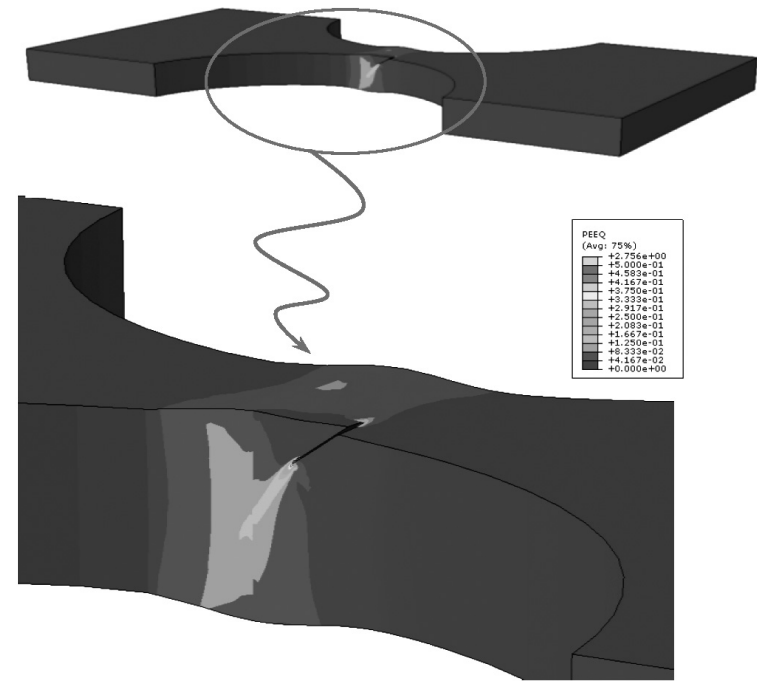

Figure 10: Plastic-strain-intensity-field distribution in the specimen from alloy 2 with a crack of a length of $0.5 \mathrm{~mm}$

Slika 10: Razporeditev polja intenzitete plastične deformacije v vzor$\mathrm{cu}$ iz zlitine $2 \mathrm{z}$ dolžino razpoke $0,5 \mathrm{~mm}$

the FE program ABAQUS. ${ }^{14}$ The specimen has its CGO near to $\langle 001\rangle$. The deviation from the axial orientation is $5.47^{\circ}$ and from the azimuthal orientation it is $41.97^{\circ}$ (the Euler angles for rotations ZX'Z' are: $\varphi=354.7^{\circ}, \theta$ $=41.7^{\circ}, \psi=89.8^{\circ}$ ). The CGO was determined with Laue diffraction patterns.

The location of the crack initiation is defined with an FE computation in section 3 and it corresponds with the experimentally obtained result. The crack propagates in plane $\langle 111\rangle$ (Figure 9), except in the rupture stage. The crack-propagation process is simulated only in plane $\langle 111\rangle$, without out-of-plane deviations, using a step-bystep technique with FE remeshing for the environment of the crack front at every step. The initial crack front has an elliptic form. The $\Delta J_{\text {eff }}$ integral is used to calculate $\Delta K_{\text {eff. }}$ The fracture zone is established by comparing the calculated $J$ integral with the $J_{\text {Ic }}$ value. The details of the simulation are described in. ${ }^{15}$

In the experiment the sample failed after 560 thermal cycles $\left(T_{\min }=150{ }^{\circ} \mathrm{C} T_{\max }=900{ }^{\circ} \mathrm{C}\right)$; the registered crack-initiation stage lasted for 435 cycles and the crack-propagation stage took 125 cycles. A comparison of the computed number of cycles for the crack-propagation stage based on the FE simulation (Figure 10) with the experimental results is given in Table $\mathbf{5}$.

A simulated crack-front evolution is shown in Figure 11a. It demonstrates a good correlation with the data of a fractography analysis (Figure 11b).

Table 5: Comparison of the estimated number of cycles for the crack-propagation stage with the experimental results (alloy 2)

Tabela 5: Primerjava določenega števila ciklov za fazo napredovanja razpok z eksperimentalnimi rezultati (zlitina 2)

\begin{tabular}{|l|c|}
\hline & Number of cycles \\
\hline FE computation with (11) & 192 \\
\hline Experiment & 125 \\
\hline
\end{tabular}




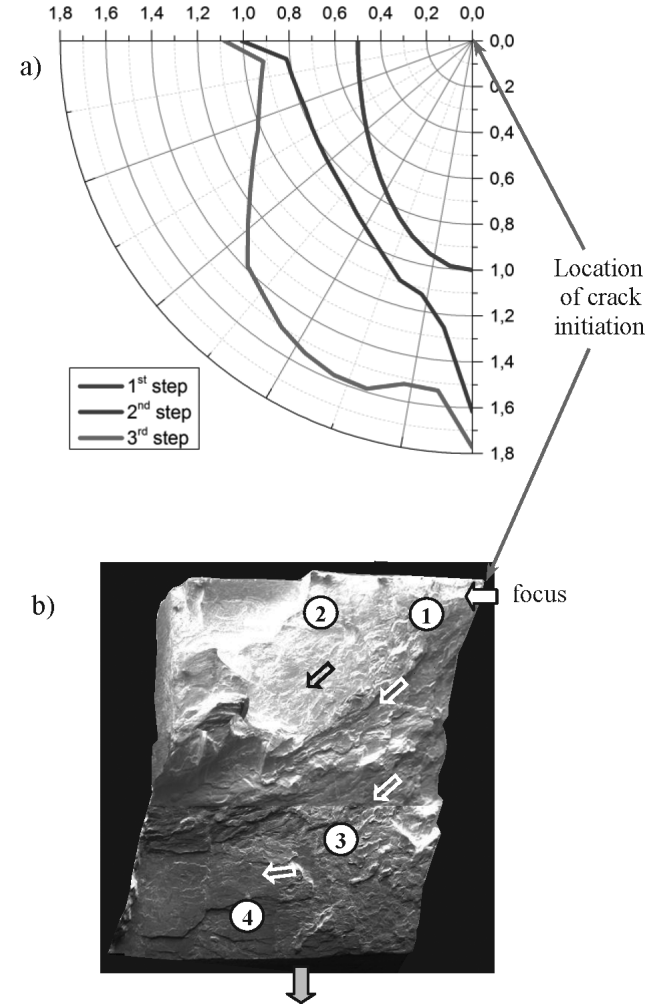

Figure 11: Evolution of the thermal-fatigue crack-front propagation on a fracture surface: a) results of finite-element simulations, b) data of a fractography analysis (specimen from alloy 2)

Slika 11: Razvoj napredovanja fronte toplotne utrujenostne razpoke na površini preloma: a) rezultati simulacije s končnimi elementi, b) podatki iz analize preloma (vzorec iz zlitine 2)

\section{CONCLUSIONS}

1. Thermal-fatigue tests were performed on corset samples from five Russian single-crystal nickel-based superalloys with various crystallographic orientations $(\langle 001\rangle,\langle 011\rangle,\langle 111\rangle)$ under different temperatures and cycle durations with the aims to determine the characteristics of the thermal-fatigue resistance, compare the alloys and determine the thermal-fatigue-failure criterion.

2. The crack-initiation criterion for the single-crystal alloys under thermal cyclic loadings is proposed and discussed. A satisfactory correlation is observed between the proposed deformation criterion (1) and the obtained experimental results.

3. The finite-element simulations of the single-crystal corset specimens under the thermal cyclic loading were performed using different material models. The obtained results indicate an applicability of the proposed deformation criteria for failure for the five considered single-crystal alloys at temperatures of up to $1100{ }^{\circ} \mathrm{C}$.

4. A high sensitivity of the thermal-fatigue durability to the crystallographic orientation and to the thermalcycle parameters is observed experimentally and also in the corresponding finite-element simulations of the corset specimens.
5. The thermal-fatigue failures of the corset specimens show the presence of crystallographic and non-crystallographic modes of failure. The occurrence of these modes depends on the crystallographic orientation and the temperature parameters of the cycle.

6. The proposed crack-propagation criterion (11) under the thermal cyclic loadings demonstrates a satisfactory accuracy in comparison with the experimentally obtained number of cycles to failure and the crackfront evolution indicated by the data of a fractography analysis.

7. To obtain reliable analysis results for the thermalfatigue strength and durability of the single-crystal blades of GTE, further detailed studies of the material characteristics, including the crack-resistance parameters, carried out over a wide temperature range, are required.

\section{Acknowledgements}

The present study is supported by Russian Science Foundation, grant No.15-19-00091.

\section{REFERENCES}

${ }^{1}$ L. B. Getsov, N. I. Dobina, A. I. Rybnikov, A. S. Semenov, A. A. Staroselsky, N. V. Tumanov, Strength of Materials, 40 (2008) 5 , 538-551, doi:10.1007/s11223-008-9076-1

${ }^{2}$ L. B. Getsov, Materials and strength of gas turbine components 1-2, Publ. House, Rybinsk 2011

${ }^{3}$ N. V. Petrushin, I. L. Svetlov, O. G. Ospenkova, Heat-resistant casting nickel alloys, All materials, Encyclopedic Handbook 6, 2012, 15-19

${ }^{4}$ A. S. Semenov, L. B. Getsov, Strength of Materials, 46 (2014) 1, 38-48, doi:10.1007/s11223-014-9513-2

${ }^{5}$ L. B. Getsov, A. S. Semenov, E. A. Tikhomirova, A. I. Rybnikov, Mater. Tehnol., 48 (2014) 2, 101-106

${ }^{6}$ L. Getsov, A. Semenov, A. Staroselsky, Mater. Tehnol., 42 (2008) 1, $3-12$

${ }^{7}$ A. S. Semenov, Proc. of V Int. Conf. Scientific and technical problems of forecasting the reliability and durability of the structures and methods for their solution, St. Petersburg, 2003, 466-480

${ }^{8}$ G. Cailletaud, International Journal of Plasticity, 8 (1992) 1, 55-73, doi:10.1016/0749-6419(92)90038-E

${ }^{9}$ J. Besson, G. Cailletaud, J. L. Chaboche, S. Forest, Non-linear mechanics of materials, $1^{\text {st }}$ ed., Springer, Netherlands 2010, doi:10.1007/978-90-481-3356-7

${ }^{10}$ U. F. Kocks, T. J. Brown, Acta Metall., 14 (1966) 2, 87-98, doi:10.1016/0001-6160(66)90290-2

${ }^{11}$ P. A. S. Reed, I. Sinclair, X. D. Wu, Metallurgical and Materials Transactions A, 31 (2000) 1, 109-123, doi:10.1007/s11661-000-0058-6

${ }^{12}$ J. Telesman, L. J. Ghosn, Accelerated fatigue crack growth behavior of PWA 1480 single crystal alloy and its dependence on the deformation mode, In: S. Reichman, D. N. Duhl, G. Maurer, S. Antolovich, C. Lund (Eds.), Superalloys 1988, The Metallurgical Society, 1988, 615-624

${ }^{13}$ A. S. Semenov, S. G. Semenov, A. A. Nasarenko, L. B. Getsov, Mater. Tehnol., 46 (2012) 3, 197-203

${ }^{14}$ ABAQUS Analysis User's Manual, Version 6.10

${ }^{15}$ S. G. Semenov, A. S. Semenov, L. B. Getsov, B. E. Melnikov, Proc. Int. XLI Summer School - Conference Advanced Problems in Mechanics, St. Petersburg, 2013, 74-81 